Article

\title{
Amphiphilic Fluorine-Containing Block Copolymers as Carriers for Hydrophobic PtTFPP for Dissolved Oxygen Sensing, Cell Respiration Monitoring and In Vivo Hypoxia Imaging with High Quantum Efficiency and Long Lifetime
}

\author{
Jiaze $\mathrm{Li}^{1,2}{ }^{\text {, Yuan Qiao }}{ }^{2}$, Tingting Pan ${ }^{2}$, Ke Zhong ${ }^{2}$, Jiaxing Wen ${ }^{2}$, Shanshan $\mathrm{Wu}^{2,3}$, \\ Fengyu Su ${ }^{4, *}$ and Yanqing Tian $2, *$ (D) \\ 1 School of Materials Science and Engineering, Harbin Institute of Technology, Nangang District, \\ Harbin 150001, China; 11749240@mail.sustc.edu.cn \\ 2 Department of Materials Science and Engineering, Southern University of Science and Technology, Xili, \\ Nanshan District, Shenzhen 518055, China; qiaoy@mail.sustc.edu.cn (Y.Q.); \\ 11553010@mail.sustc.edu.cn (T.P.); 11612419@mail.sustc.edu.cn (K.Z.); 11510869@mail.sustc.edu.cn (J.W.); \\ 2018090123@gdip.edu.cn (S.W.) \\ 3 Light Chemical Technology College, Guangdong Industry Polytechnic, Haizhu District, \\ Guangzhou 510300, China \\ 4 SUSTech Academy for Advanced Interdisciplinary Studies, Southern University of Science and Technology, \\ Xili, Nanshan District, Shenzhen 518055, China \\ * Correspondence: fysu@sustc.edu.cn (F.S.); tianyq@sustc.edu.cn (Y.T.); Tel.: +86-755-8801-8997
}

Received: 3 October 2018; Accepted: 29 October 2018; Published: 2 November 2018

check for updates

\begin{abstract}
New amphiphilic star or multi-arm block copolymers with different structures were synthesized for enabling the use of hydrophobic oxygen probe of platinum (II)-tetrakis (pentafluorophenyl) porphyrin (PtTFPP) for bioanalysis. The amphiphilic star polymers were prepared through the Atom Transfer Radical Polymerization (ATRP) method by using hydrophilic 4-arm polyethylene glycol (4-arm-PEG) as an initiator. Among the five block copolymers, P1 series (P1a, P1b, and P1c) and P3 possess fluorine-containing moieties to improve the oxygen sensitivity with its excellent capacity to dissolve and carry oxygen. A polymer P2 without fluorine units was also synthesized for comparison. The structure-property relationship was investigated. Under nitrogen atmosphere, high quantum efficiency of PtTFPP in fluorine-containing micelles could reach to $22 \%$ and long lifetime could reach to $76 \mu \mathrm{s}$. One kind of representative PtTFPP-containing micelles was used to detect the respiration of Escherichia coli (E. coli) JM109 and macrophage cell J774A.1 by a high throughput plate reader. In vivo hypoxic imaging of tumor-bearing mice was also achieved successfully. This study demonstrated that using well-designed fluoropolymers to load PtTFPP could achieve high oxygen sensing properties, and long lifetime, showing the great capability for further in vivo sensing and imaging.
\end{abstract}

Keywords: dissolved oxygen sensors; fluoropolymers; micelles; cell respiration monitoring; tumor imaging

\section{Introduction}

Dissolved oxygen (DO) is crucial to environment, industry, life technology, and human health, etc. Hypoxia [1] $\left(\leq 0.5 \% \mathrm{O}_{2}\right.$, usually at tumor environments) is relevant to cancer, stroke [2], arteriosclerosis [3], Parkinsonism [4], Alzheimer's disease [5], etc. It has been reported that oxygen played an important role when methyl group from DNA was removed by enzymes. Otherwise, 
hypermethylation could result in abnormal cell behavior and rapid growth of tumors [6]. At the gene level, the hypoxia-inducible factor- $1 \alpha$ (HIF- $1 \alpha)$ maintained the in vivo oxygen homeostasis $[7,8]$. On the other hand, hypoxia can also influence clinical surgery such as radiotherapy, because low-level oxygen condition will decrease the radiation efficiency [9]. Until now, DO sensing and imaging have remained to be a challenge in biology, medicine, the environment and the food industry. There are several ways to detect dissolved oxygen such as Clark electrodes [10], Winkler titration [11] and optical sensors [12]. The first two methods have been developed maturely, but there are still limitations. Clark electrode can only measure the relative oxygen content of air and samples [13], while Winkler titration is unsuitable for real-time continuous oxygen detection [14], and both approaches consume oxygen during detection. Phosphorescence based optical oxygen analysis makes up for the shortfalls of the first two methods with the following characters: (1) noninvasive and reversible sensing; (2) without oxygen consumption; (3) high sensitivity to oxygen with fast responses; and (4) capable for single cell level sensing. These properties gave huge potentials for phosphorescence oxygen sensing in biological application [15-17].

Metalloporphyrin derivatives are typical oxygen sensors possessing excellent optical stability and significant oxygen quenching properties. For instance, platinum (II)-tetrakis (pentafluorophenyl) porphyrin (PtTFPP) as one of the best oxygen probes has a long lifetime and super photo bleaching resistance [18]. However, PtTFPP is extremely hydrophobic, resulting in its unsuitableness for in vitro and further in vivo dissolved oxygen sensing. In order to enable the application of PtTFPP and its derivatives for biostudies, scientists have explored a few approaches along this direction, including the generation of nanoparticles with the assistance of conjugated polymers $[19,20]$, the conjugation of PtTFPP-derivatives into the main-chain of conjugated polymers [21-23], and the encapsulation of the porphyrin probe into the micelles formed from amphiphilic block or graft copolymers [24], etc. We have been using the micelle approach to transfer PtTFPP into aqueous solution for oxygen sensing by using linear block copolymer and graft copolymers [25-27]. However, there is no systematical investigation of structure-property relationships.

Considering the abundance of polymer structures, herein we extended this study to multi-arm block copolymers. A modified 4-arm polyethylene glycol (4-Arm-PEG) as a hydrophilic chain was used as an initiator to polymerize three kinds of monomers to achieve five kinds of block copolymers with different structures. We chose two kinds of fluorine-containing monomers with different fluorine-units for hydrophobic chains and one fluorine-free monomer (styrene) for comparison. Thus structure-properties can be evaluated. The use of multi-arm block copolymers is due to their good stability, high drug loading ratios and long in vivo circulation time [28,29]. On the other hand, fluorine is super hydrophobic. It has been reported that micelles formed from fluorine-containing amphiphilic polymers exhibited high stability and nontoxicity which can be used as protein drug carriers [30]. Based on the former research on perfluorocarbon oxyglobin, fluorine has greater capacity to dissolve, carry and permeate oxygen [31]. Besides, the presence of halide substituents could increase the photostability of metalloporphyrins [32]. Therefore, these fluorine-containing amphiphilic block copolymers are expected to have excellent compatibility with the fluorine-containing PtTFPP to achieve high quantum efficiencies of the PtTFPP in aqueous solution as well as high oxygen sensitivity. After evaluating the structure-properties relationship, representative micelles will be used for cell respiration monitoring and in vivo hypoxia imaging.

\section{Materials and Methods}

\subsection{Materials and Reagents}

PtTFPP was purchased from Frontier Scientific (Logan, UT, USA). Hexafluorobutyl methacrylate (HFMA) stabilized with hydroquinone monomethyl ether (MEHQ) and $\alpha$-bromoisobutyryl bromide were acquired from TCI (Tokyo, Japan). Styrene stabilized with 4-tert-buytlcatechol (TBC) and trifluoroethyl methacrylate (TFEMA) stabilized with MEHQ were obtained from Aladdin 
(Shanghai, China). The 4-arm-PEG-OH, 4-(2-hydroxyethyl)-1-piperazineethanesulfonic acid (HEPES), 1,1,4,7,7-pentamethyl-diethylenetriamin (PMDETA), and CuBr were purchased from Creative PEGWorks (Chapel Hill, NC, USA), Sigma-Aldrich (St. Louis, MO, USA), Energy Chemical (Shanghai, China), and J \& K Scientific Ltd. (Shanghai, China), respectively. All the monomers used for polymerization were purified by passing through a basic $\mathrm{Al}_{2} \mathrm{O}_{3}$ column to remove the stabilizer before used. The monocyte macrophage J774A.1 cell line was provided by GuangZhou Jennio Biotech Co., Ltd. (Guangzhou, China). The human breast adenocarcinoma cell line MCF-7 was obtained from Shanghai Zhong Qiao Xin Zhou Biotechnology Co., Ltd (Shanghai, China).

\subsection{Instruments}

Water 1515 gel permeation chromatography (GPC) coupled with a refractive index (RI) detector (Waters, Milford, MA, USA) and nuclear magnetic resonance spectroscopy (NMR) (Bruker Avance III $400 \mathrm{M}$, Karlsruhe, Germany) were used to determine relative molecular weights of polymers. Dynamic light scattering (DLS) (Malvern Nano ZS, Malvern, WR, UK) was used to measure the diameters of micelles. Fluorescence Spectrofluorophotometer (PerkinElmer LS 55, Shelton, CT, USA) was applied to measure photo-luminescence intensities. A gas manipulator (Alicat Scientific Instrument, Tucson, AZ, USA, measuring error: $<1 \%$ ) was used for controlling the exact gas percentage during phosphorescence measurements. Transient Absorption Spectrometer (FLS 980, Edinburch Instruments Ltd., Livingston, UK) was used to detect phosphorescence lifetimes. A Plate Reader (BioTek Cytation 3, Winooski, VT, USA) was used for toxicity test and respiration measurements of Escherichia coli (E. coli) and cells.

\subsection{Synthesis of Macroinitiator 4-Arm-PEG-Br and Amphiphilic Star Polymers}

Macroinitiator 4-arm-PEG-Br (Scheme 1): $5.0 \mathrm{~g}$ (0.5 mmol) of 4-Arm-PEG-OH and $0.7 \mathrm{~mL}$ ( $5 \mathrm{mmol}$ ) of $\mathrm{Et}_{3} \mathrm{~N}$ were added into $100 \mathrm{~mL}$ of ultra-dry dichloromethane (DCM). A total of $0.6 \mathrm{~mL}$ (5 mmol) of $\alpha$-Bromoisobutyryl bromide was dissolved in $25 \mathrm{~mL}$ of anhydrous DCM and slowly dropped into the mixture solution in an ice bath under stirring. After $24 \mathrm{~h}$, the mixed solution was precipitated in ice cooled ether to get the macroinitiator. The crude product was dissolved in water $(\mathrm{pH}=9)$ and extracted by dry DCM to remove the triethylamine hydrochloride thoroughly. Yield: $79 \% .{ }^{1} \mathrm{H}$ NMR $\left(400 \mathrm{MHz}, \mathrm{CDCl}_{3}, \delta(\mathrm{ppm})\right): 4.33\left(\mathrm{t}, 2 \mathrm{H},-\mathrm{CH}_{2} \mathrm{OCO}-\right), 3.64\left(\mathrm{~m}, 230 \mathrm{H},-\mathrm{OCH}_{2} \mathrm{CH}_{2} \mathrm{O}-\right), 1.94(\mathrm{~s}, 6 \mathrm{H}$, $\left.-\mathrm{CCH}_{3}-\right) . \mathrm{M}_{\mathrm{n}(\mathrm{NMR})}=10,940, \mathrm{M}_{\mathrm{n}(\mathrm{GPC})}=3960, \mathrm{M}_{\mathrm{w}(\mathrm{GPC})} / \mathrm{M}_{\mathrm{n}(\mathrm{GPC})}=1.1$.

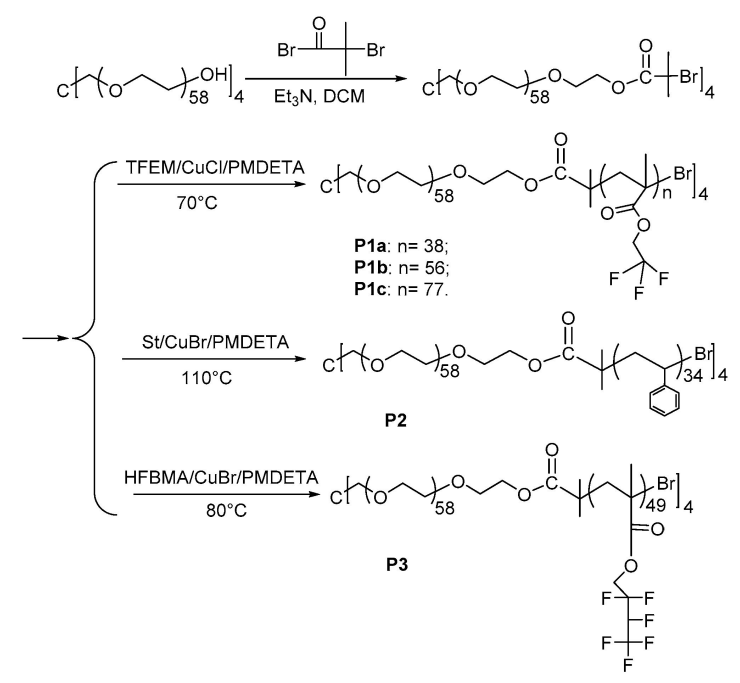

Scheme 1. Synthesis of 4-arm-PEG- Br macroinitiator and its star block copolymers.

P1a: A total of $0.266 \mathrm{~g}(0.025 \mathrm{mmol})$ of the 4 -arm-PEG-Br and $10 \mathrm{mg}(0.1 \mathrm{mmol})$ of $\mathrm{CuCl}$ were added into a Schlenk tube, and the Schlenk tube was vacuumed for $15 \mathrm{~min}$. A solution of $0.58 \mathrm{~mL}$ ( $5 \mathrm{mmol}$ ) of trifluoroethyl methacrylate and $20 \mu \mathrm{L}(0.1 \mathrm{mmol})$ of PMDETA in $3 \mathrm{~mL}$ of anisole was slowly injected 
into the Schlenk tube. After three times freeze-thaw procedure to remove residual oxygen, the Schlenk tube was placed in a $70^{\circ} \mathrm{C}$ oil bath for $24 \mathrm{~h}$. After the polymeric solution was passed through neutral $\mathrm{Al}_{2} \mathrm{O}_{3}$ column to remove copper, the polymer was obtained by precipitating in excess cold n-hexane to get P1a with a yield of 50\%. ${ }^{1} \mathrm{H} \mathrm{NMR}\left(400 \mathrm{MHz}, \mathrm{CDCl}_{3}, \delta(\mathrm{ppm})\right): 4.34\left(\mathrm{~s}, 76 \mathrm{H},-\mathrm{OCH}_{2} \mathrm{CF}_{3}-\right) ; 3.64$ $\left(\mathrm{m}, 230 \mathrm{H},-\mathrm{OCH}_{2} \mathrm{CH}_{2} \mathrm{O}-\right) . \mathrm{M}_{\mathrm{n}(\mathrm{NMR})}=33,790, \mathrm{M}_{\mathrm{n}(\mathrm{GPC})}=5340, \mathrm{M}_{\mathrm{w}(\mathrm{GPC})} / \mathrm{M}_{\mathrm{n}(\mathrm{GPC})}=1.3$.

P1b was obtained by the same method as P1a, except the feed ratio of monomer to the macroinitiator was 400:1. Yield: 44\%. ${ }^{1} \mathrm{H} \mathrm{NMR}\left(400 \mathrm{MHz}, \mathrm{CDCl}_{3}, \delta(\mathrm{ppm})\right.$ ): 4.34 (s, $\left.112 \mathrm{H},-\mathrm{OCH}_{2} \mathrm{CF}_{3^{-}}\right)$; $3.64\left(\mathrm{~m}, 230 \mathrm{H},-\mathrm{OCH}_{2} \mathrm{CH}_{2} \mathrm{O}-\right) . \mathrm{M}_{\mathrm{n}(\mathrm{NMR})}=45,880, \mathrm{M}_{\mathrm{n}(\mathrm{GPC})}=7650, \mathrm{M}_{\mathrm{w}(\mathrm{GPC})} / \mathrm{M}_{\mathrm{n}(\mathrm{GPC})}=1.2$.

P1c was attained by the same way as P1a, except the feed ratio of monomers to the macroinitiator was 600:1. Yield: 40\%. ${ }^{1} \mathrm{H}$ NMR (400 $\left.\mathrm{MHz} \mathrm{CDCl}_{3}, \delta(\mathrm{ppm})\right): 4.34\left(\mathrm{~s}, 154 \mathrm{H},-\mathrm{OCH}_{2} \mathrm{CF}_{3}-\right) ; 3.64(\mathrm{~m}$, $\left.230 \mathrm{H},-\mathrm{OCH}_{2} \mathrm{CH}_{2} \mathrm{O}-\right) \cdot \mathrm{M}_{\mathrm{n}(\mathrm{NMR})}=62,680, \mathrm{M}_{\mathrm{n}(\mathrm{GPC})}=10,710, \mathrm{M}_{\mathrm{w}(\mathrm{GPC})} / \mathrm{M}_{\mathrm{n}(\mathrm{GPC})}=1.3$.

P2 was synthesized through the same method as P1a, however using styrene as the monomer and the reaction temperature was set at $110{ }^{\circ} \mathrm{C}$. Yield: $26 \% .{ }^{1} \mathrm{H} \mathrm{NMR}\left(400 \mathrm{MHz}, \mathrm{CD}_{2} \mathrm{Cl}_{2}, \delta(\mathrm{ppm})\right)$ : 6.46-7.08 (m, $171 \mathrm{H}, \mathrm{ArH}) ; 3.58\left(\mathrm{~m}, 230 \mathrm{H},-\mathrm{OCH}_{2} \mathrm{CH}_{2} \mathrm{O}-\right) . \mathrm{M}_{\mathrm{n}(\mathrm{NMR})}=24,780, \mathrm{M}_{\mathrm{n}(\mathrm{GPC})}=6280$, $\mathrm{M}_{\mathrm{w}(\mathrm{GPC})} / \mathrm{M}_{\mathrm{n}(\mathrm{GPC})}=1.2$.

P3 was acquired by the same method as P1a, however using hexafluorobutyl methacrylate as the monomer and the reaction temperature was set at $80{ }^{\circ} \mathrm{C}$. Yield: $48 \%$. ${ }^{1} \mathrm{H} \mathrm{NMR}(400 \mathrm{MHz}$, $\mathrm{CDCl}_{3}, \delta$ (ppm)): 4.85 (m, 49 H, -CHF-); 4.35 (s, $96 \mathrm{H},-\mathrm{OCH}_{2}-$ ); 3.64 (m, $\left.230 \mathrm{H},-\mathrm{OCH}_{2} \mathrm{CH}_{2} \mathrm{O}-\right)$. $\mathrm{M}_{\mathrm{n}(\mathrm{NMR})}=59,220, \mathrm{M}_{\mathrm{n}(\mathrm{GPC})}=8370, \mathrm{M}_{\mathrm{w}(\mathrm{GPC})} / \mathrm{M}_{\mathrm{n}(\mathrm{GPC})}=1.5$.

\subsection{Preparation of Micelles with PtTFPP}

A total of $30 \mathrm{mg}$ of each polymer in $1.2 \mathrm{~mL}$ of tetrahydrofuran (THF) and $2 \mathrm{mg}$ of PtTFPP in $200 \mu \mathrm{L}$ of THF were mixed then added slowly into $6 \mathrm{~mL}$ of deionized water under fast stirring. The solutions were dialyzed against water for 2 days. Then, the solutions were passed through $0.45 \mu \mathrm{m}$ filter membranes and stored in a brown bottle at $4{ }^{\circ} \mathrm{C}$ for further use. For biological application, the micelles were dialyzed again against HEPES solution for 2 days. The micelles formed from P1a, P1b, P1c, P2 and P3 were named as M1a, M1b, M1c, M2 and M3, respectively. The concentration of PtTFPP packed in micelles was detected by UV-Vis Absorption Spectra.

\subsection{Critical Micelle Concentrations Determination of Block Polymers}

As there is no luminescent group in these amphiphilic polymers, we used pyrene approach to determine the critical micelle concentrations (CMC) of the block copolymers. The fluorescence spectrum of pyrene has five peaks $[33,34]$. The intensity ratio of the first peak $(373 \mathrm{~nm})$ to the third peak (384 nm) will decrease with the decline of solution polarity. Thus, CMC was measured by mixing pyrene in different concentrations of polymer solutions, and the $\mathrm{I}_{373} / \mathrm{I}_{384}$ value will decrease to a constant when and the pyrene transferred from water to micelles, which means the formation of pyrene-containing micelles.

\subsection{Quantum Efficiency Determination}

Quantum efficiency measurement was carried out under nitrogen atmosphere. As is reported in former literature, quantum efficiency of PtTFPP in DCM is 0.088 [35]. Setting this value as a reference, we can calculate PtTFPP-containing micelles' quantum efficiencies by using the emission intensity and absorbance of PtTFPP in micelles and in DCM, respectively (Equation (1)).

$$
\eta_{\mathrm{s}}=\eta_{r}\left(\frac{A_{r}}{A_{s}}\right)\left(\frac{I_{s}}{I_{r}}\right)\left(\frac{n_{s}^{2}}{n_{r}^{2}}\right) .
$$

In the Equation (1) [36], $\eta_{r}$ is the quantum efficiency of PtTFPP in DCM; $n_{r}$ is the refractive index of DCM $\left(n_{r}=1.424\right) ; n_{S}$ is the refractive index of water $\left(n_{S}=1.333\right) ; A_{r}$ and $A_{S}$ indicate the absorbance 
of reference and samples respectively; $I_{r}$ and $I_{s}$ indicate the phosphorescence intensities of reference and samples, respectively.

\subsection{Response to Oxygen}

Due to the special oxygen quenching property of PtTFPP, higher oxygen concentration results in lower emission intensity. A total of $3 \mathrm{~mL}$ of Micelle solution was placed in a quartz cell, oxygen concentration was adjusted by bubbling mixed gases of oxygen and nitrogen with various ratios into the micelle solutions. Emission spectra were measured under an excitation wavelength of $405 \mathrm{~nm}$.

\subsection{Response Time Measurement}

Similar to the oxygen titration, we detected the dynamic relationship between phosphorescence intensity and time through phosphorescence spectra (excitation: $405 \mathrm{~nm}$; emission: $650 \mathrm{~nm}$ ). We defined the response time as the time corresponding to the intensity that $95 \%$ of the difference between maximum intensity and minimum intensity when the atmosphere switched between $100 \%$ oxygen and $100 \%$ nitrogen.

\subsection{Phosphorescence Lifetime Determination}

A Transient Absorption Spectrometer was used to measure the phosphorescence decay time of PtTFPP-containing micelles under air and nitrogen respectively.

\subsection{E. coli Culture}

E. coli JM109 was cultivated in Luria-Bertani (LB) medium at $37^{\circ} \mathrm{C}$ under shaking. Through measuring the E. coli optical density (OD) value (from 0.1 to 1 ) at $600 \mathrm{~nm}$ by UV-Vis Absorption Spectrometer, the density of E. coli was obtained. $\mathrm{OD}_{600}$ of 1 equals to $5 \times 10^{8} \mathrm{cfu} / \mathrm{mL}$. Appropriate densities were diluted with LB medium.

During toxicity measurement, several densities of E. coli were added into a 96-well plate. The micelles added into each well contained $10 \mu \mathrm{g} / \mathrm{mL}$ of PtTFPP. The wells without sensors were set as the control group. The experiment was executed through a plate reader at $37^{\circ} \mathrm{C}$ with an oil seal. In another group of parallel experiments, $4 \times 10^{7} \mathrm{cfu} / \mathrm{mL}$ of $E$. coli was added to another 96-well plate, while different concentrations of the PtTFPP-containing micelles were added.

In the respiration detection, we also used a plate reader to collect the changes in phosphorescence intensity over time among different densities of E. coli. At the early stage of the experiment, the emission intensity will decrease due to the temperature equilibrating issue or temperature effect [26,27], so we stabilized the samples for $20 \mathrm{~min}$ before the detection.

\subsection{Cell Culture}

J774A.1 cells were cultured in a mixture medium containing $89.1 \%$ of Dulbecco's modified eagle medium (DMEM) medium, $9.9 \%$ of fetal bovine serum (FBS) and $1 \%$ of penicillin-streptomycin. After being cultivated at $37^{\circ} \mathrm{C}$ in $5 \%$ of $\mathrm{CO}_{2}$ incubator, cells were vaccinated on 96-well plates for toxicity and respiration experiments.

MCF-7 cells were cultured in the same medium as J774A.1. After being cultivated at $37^{\circ} \mathrm{C}$ in $5 \%$ of $\mathrm{CO}_{2}$ incubator, MCF-7 cells were used for tumor formation in the animal experiment.

\subsection{Mice Culture and In Vivo Imaging}

Female Balb/c nude mice were purchased from Beijing Vital River Laboratory Animal Technology Co., Ltd. and fed in a Specific Pathogen Free (SPF) animal facility. A total of $100 \mu \mathrm{L}$ of MCF-7 cells $\left(1 \times 10^{7}\right.$ cells $\left./ \mathrm{mL}\right)$ were injected into the left hind leg of each Balb/c nude mouse. Two weeks after MCF-7 cells injection, tumor imaging was carried on through an In Vivo Imaging System. Before imaging, the PtTFPP-containing micelles were injected into the tumor and subcutis of mice, respectively. 
The animal experiment followed the Guidelines for the Care and Use of Research Animals established by the Southern University of Science and Technology Laboratory Animal Center (SUSTC-JY2018078).

\section{Results and Discussion}

\subsection{Design and Synthesis of Block Copolymers}

A few kinds of 4-arm amphiphilic block copolymers were synthesized (Scheme 1). These amphiphilic block copolymers can form micelles for encapsulating hydrophobic PtTFPP into their micelles to enable the application of PtTFPP in aqueous conditions. Some studies revealed that the micelles formed from multi-arm block copolymers may exhibit more morphologies and assemblies than linear polymers [37,38] as well as better stability and longer in vivo cycle time [28,29]. Herein we explore whether these amphiphilic 4-arm block copolymers can be used for systemically studying structure-property relationships in the field of oxygen sensing and for cell metabolism related research. For understanding structure-property relationships, five block copolymers were synthesized. P1a, P1b, P1c, and P3 possess fluorine moieties. The side-chain of $\mathbf{P} 3$ possesses more fluorine units than those of P1 series. P2 does not contain fluorine moieties. Polymers with fluorine units are expected to have better compatibility with the hydrophobic fluorine-containing-PtTFPP to achieve high quantum efficiency and also for excellent sensitivity. Hydrophobic-hydrophilic ratios were also tuned to see whether these ratios have influences on photo-physical properties by using P1a, P1b, and P1c as three typical polymers. The block copolymers were synthesized by using ATRP-a kind of controlled living polymerization [39-41]. Through the tuning monomers and/or monomer/macroinitiator molar ratios, five different polymers were synthesized successfully. The polymers were characterized by using NMR and GPC. Their typical ${ }^{1} \mathrm{H}$ NMR spectra and ${ }^{19} \mathrm{~F}$ NMR spectra were given in Figure 1, Supplementary Figures S1 and S2. Detailed data of these polymers were given in Table 1.

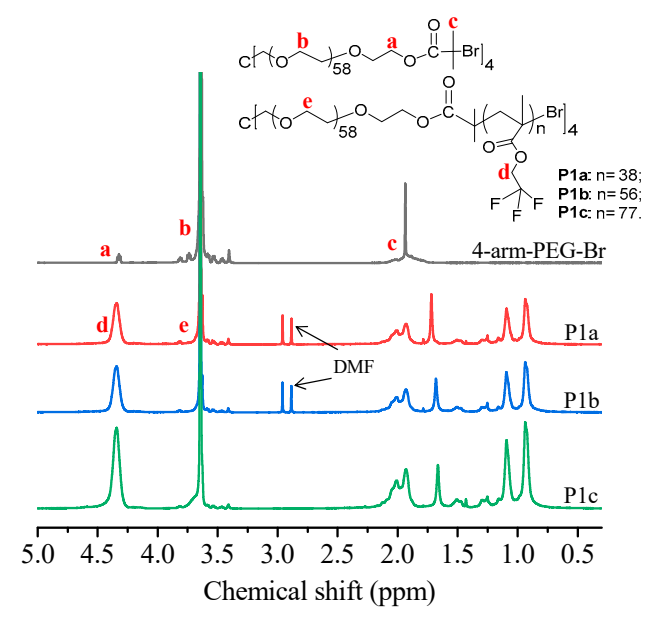

Figure 1. ${ }^{1} \mathrm{H}$ NMR spectra of 4-arm-PEG-Br, P1a, P1b, and P1c.

Table 1. Yields, conversions and characters of the star polymers.

\begin{tabular}{ccccccc}
\hline & Yield (\%) & Conv. (\%) & $\mathbf{M}_{\mathbf{n}(\mathrm{NMR})}$ & $\mathbf{M}_{\mathbf{n}(\mathrm{GPC})}$ & $\mathbf{M}_{\mathbf{w}} / \mathbf{M}_{\mathbf{n}}$ & $\begin{array}{c}\mathbf{C M C} \\
(\mu \mathrm{g} / \mathbf{m L})\end{array}$ \\
\hline 4-arm-PEG-Br & 79 & - & 10,940 & 3960 & 1.1 & - \\
P1a & 50 & 76 & 33,790 & 5340 & 1.3 & 6.9 \\
P1b & 44 & 56 & 45,880 & 7650 & 1.2 & 8.8 \\
P1c & 40 & 51 & 62,680 & 10,710 & 1.3 & 10.5 \\
P2 & 26 & 34 & 24,780 & 6280 & 1.2 & 5.7 \\
P3 & 48 & 49 & 59,220 & 8370 & 1.5 & 6.0 \\
\hline
\end{tabular}

$\mathrm{NMR}=$ nuclear magnetic resonance spectroscopy; GPC = gel permeation chromatography. 


\subsection{Critical Micelle Concentrations Determination}

The CMC is an important factor for micelle formation and stability. CMCs of these polymers were determined by using the traditional Pyrene-encapsulation approach that we mentioned in the experiments section. Through the determination of pyrene's aggregations in micelles by observing its excimer formation and ratios, CMCs were determined to be 5.7 to $10.5 \mu \mathrm{g} / \mathrm{mL}$ (Table 1), slightly affected by polymer structures. The ranges of CMC were comparable to some reported linear block copolymers [42], showing that these multi-arm bock copolymers' micelles exhibit similar stability with other common linear block copolymers. Structure influences on the CMCs were observed. Longer hydrophobic segments induced slightly larger CMC as compared within the P1 series. Most likely, the length of PEG may uneasily stabilize the longer hydrophobic segments in P1 series, to result in higher $\mathrm{CMC}$ in higher molecular weight polymers.

\subsection{Micelle Preparation and Their Photophysical Properties}

The preparation of micelles was illustrated in Figure 2. The hydrophobic segments of the polymers formed micellar cores and the hydrophilic PEG segments formed hydrophilic shells to encapsulate the hydrophobic PtTFPP in the micellar cores. This approach enabled the application of PtTFPP in aqueous solutions.

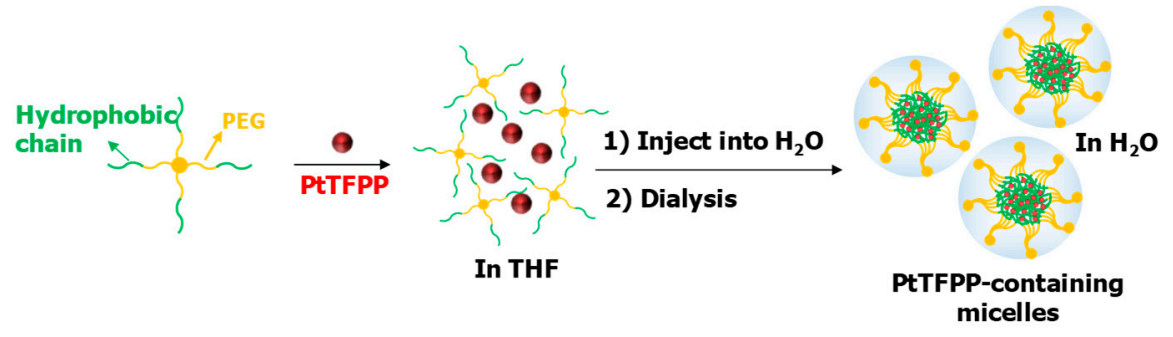

Figure 2. The preparation process of micelles.

The DLS was used to measure micelles diameters (Figure 3). Detailed data were given in Table 2. It was found that the micelles' diameters were in the range of 122 to $163 \mathrm{~nm}$. P1c has the lowest encapsulation efficiency for PtTFPP, although it has the highest molecular weights among the P1 series polymers. This might be due to the poor solubility of P1c in water with the longest hydrophobic chain. Additionally, the encapsulation efficiency for PtTFPP for all the three P1 series polymers is smaller than the polymers with polystyrene chains (P2) and longer alkyl chains with more fluorine units (P3), showing the polymer structures' influence on sensing probes loading.
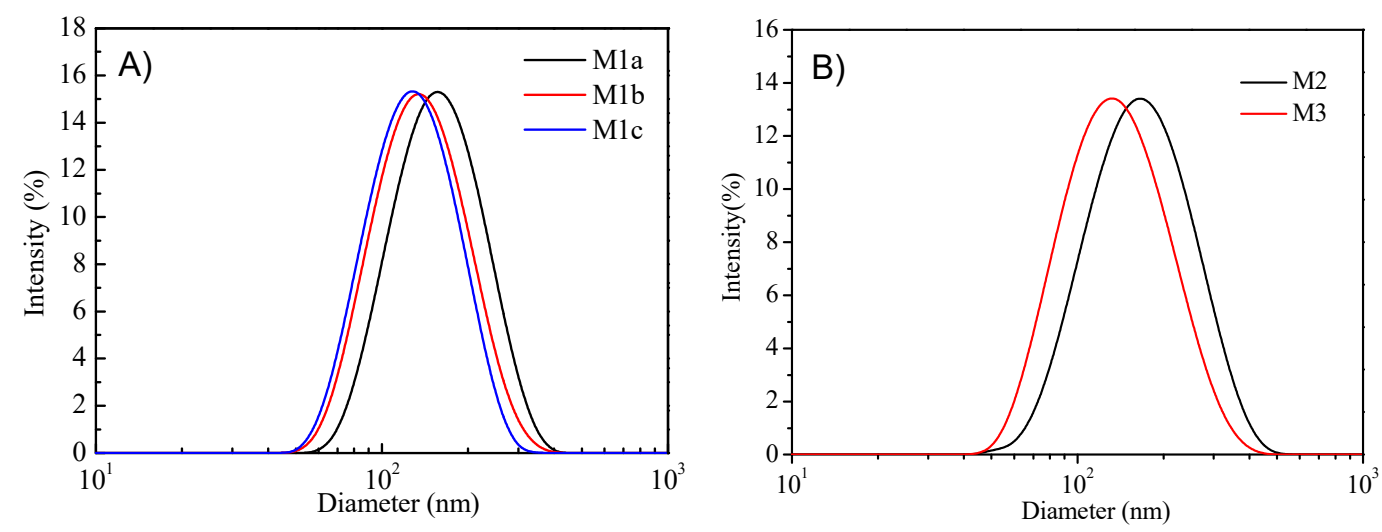

Figure 3. Dynamic light scattering (DLS) results of the PtTFPP-containing micelles: M1b, M1c (A) and M2, M3 (B). 
Table 2. Characterization of the five kinds of PtTFPP-containing micelles.

\begin{tabular}{|c|c|c|c|c|c|c|c|c|c|c|c|c|}
\hline \multirow[t]{2}{*}{ Micelles } & \multirow[t]{2}{*}{$\begin{array}{l}\text { Diameter } \\
(\mathrm{nm})\end{array}$} & \multirow[t]{2}{*}{ a PDI } & \multirow[t]{2}{*}{$\begin{array}{c}\text { Con (Polymer) } \\
(\mathrm{mg} / \mathrm{mL})\end{array}$} & \multirow[t]{2}{*}{$\begin{array}{l}\text { Con (PtTFPP) } \\
(\mathrm{mg} / \mathrm{mL})^{b}\end{array}$} & \multirow[t]{2}{*}{$\begin{array}{c}\text { Encapsulation } \\
\text { Efficiency } \\
(w t \%)\end{array}$} & \multirow[t]{2}{*}{$\begin{array}{c}\text { Quantum } \\
\text { Efficiency } \\
(\%)\end{array}$} & \multicolumn{2}{|c|}{${ }^{c} I_{0} / I_{100}$} & \multicolumn{2}{|c|}{$\begin{array}{c}\mathrm{d} \text { Response } \\
\text { Time (s) }\end{array}$} & \multicolumn{2}{|c|}{$\begin{array}{c}\text { e Lifetime } \\
(\mu s)\end{array}$} \\
\hline & & & & & & & $25^{\circ} \mathrm{C}$ & $37^{\circ} \mathrm{C}$ & $t_{95-r}$ & $t_{95}$ & Air & $\mathrm{N}_{2}$ \\
\hline M1b & 142 & 0.27 & 0.38 & 0.13 & 39 & 22.3 & 15 & 27 & 204 & 31 & 22 & 72 \\
\hline M1c & 122 & 0.34 & 0.34 & 0.06 & 18 & 21.5 & 11 & 28 & 191 & 30 & 29 & 70 \\
\hline M2 & 145 & 0.17 & 1.11 & 0.31 & 93 & 11.8 & 8 & 10 & 163 & 34 & 25 & 66 \\
\hline
\end{tabular}

a Polymer dispersity index (PDI) is used to describe the molecular size distribution. ${ }^{\mathrm{b}}$ PtTFPP concentration in micelles was measured by referring PtTFPP absorption standard curve. ${ }^{c}$ Phosphorescence intensity ratio under $100 \% \mathrm{~N}_{2}$ to $100 \% \mathrm{O}_{2} \cdot{ }^{\mathrm{d}}$ The values reported here are only applicable to the discussion of the system in this paper. ${ }^{\mathrm{e}}$ Micelles phosphorescence lifetime in air and $\mathrm{N}_{2}$ atmosphere respectively. Con: The abbreviation of concentration.

Quantum efficiencies of the PtTFPP molecules in these micelles could be achieved as high as 22.3\% by using the fluorine-containing polymers P1 series. Among the five polymers, P2's micelles without fluorine moieties possess the lowest quantum efficiency of $11.8 \%$. This comparison indicates the advantage of the use of the fluorine-containing polymers for achieving high quantum efficiency of PtTFPP in aqueous solutions. This result was also supported by the long lifetime of the PtTFPP in fluorine-containing micelles (70-76 $\mu$ s for P1a, P1b, P1c, and P3 under nitrogen, Table 2 and Figure S3), because of the high hydrophobicity and compatibility of the fluorine moieties in the hydrophobic side-chains with the fluorine-containing PtTFPP. Previous studies showed that the phosphorescence lifetime of a well-designed nano-metal organic framework (MOF) probe which contained $\mathrm{Pt}(\mathrm{II})$-porphyrin ligand as an $\mathrm{O}_{2}$ sensitive part and Rhodamine $\mathrm{B}$ isothiocyanate ligand as an $\mathrm{O}_{2}$-insensitive part was $28.1 \mu$ s under deoxygenated atmosphere [43]; a conjugated Pdots with fluorescence resonance energy transfer (FRET) exhibited $33.7 \mu$ s phosphorescence lifetime under nitrogen [21]; and an intracellular nanoparticle probe composed of cationic polymer as shell and PtTFPP as core possessed $70 \mu$ s hypoxia phosphorescence lifetime attributed to the excellent loading property of the purchased polymer [44]. Lehner et al. reported an oxygen sensing device which embedded PtTFPP in a polymer matrix to improve the lifetime of PtTFPP to $90 \mu \mathrm{s}$, however, it is bulk material instead of nanoparticle [45]. Therefore, the lifetime in the range of 70-76 $\mu$ s reported here is among the longest ones in the known literature, showing the advantage of the use of fluorine-containing multi-arm block copolymers. On the other hand, previously we reported that PtTFPP in micelles could achieve high quantum efficiency of 20-23\%, however through FRET enhancement $[27,30]$.

It is worth noting here that metalloporphyrin's hydrophobicity results in their difficulty for application in water. Previous studies showed that water-soluble platinum porphyrins' quantum efficiency was less than 1\% in water [46]. Dendrimer's approach was utilized to prevent the interaction of the platinum porphyrin units with water to achieve high quantum efficiency of 7.3\% [47], however, dendrimers require long synthesis steps and a further purification process. Ruslan et al. reported the use of conjugated polymer nanoparticles to achieve high quantum yield of $18 \%$ of platinum porphyrin-derivatives [23].

Therefore, through the above discussion, this study showed the advantage of using fluorine-derived multi-arm amphiphilic block copolymers for transferring hydrophobic PtTFPP into aqueous system for oxygen sensing.

\subsection{Oxygen Sensing Properties}

The micelles' response to oxygen was measured by adjusting the DO concentrations through the bubbling mixed oxygen and nitrogen into the micellar solutions. Figure $4 \mathrm{~A}$ showed the representative oxygen responses by using the micelles formed from P3 and PtTFPP (M3) at $25^{\circ} \mathrm{C}$. It was found that with the increase of oxygen concentration, the emission intensity decreased. Since most biological application was carried out at $37^{\circ} \mathrm{C}$, the sensing response was also measured at $37^{\circ} \mathrm{C}$, and a similar phenomenon was observed (Figure S4). The responses followed the linear Stern-Volmer equation 
(Equation (2) and Figure 4B), where $I_{0}$ is PtTFPP's maximum intensity at $650 \mathrm{~nm}$ under nitrogen; $I$ is the intensity at $650 \mathrm{~nm}$ under various DO concentrations, $K_{S V}$ is the Stern-Volmer constant, $\left[\mathrm{O}_{2}\right]$ is the dissolved oxygen concentration.

$$
\frac{I_{0}}{I}=1+K_{S V}\left[O_{2}\right]
$$

Similar to other oxygen sensors [48], the sensitivity at $37^{\circ} \mathrm{C}$ was higher than that at $25^{\circ} \mathrm{C}$, because of the more interaction activity of the oxygen molecules with the probe of PtTFPP at higher temperature. The sensitivity $\left(I_{0} / I_{100}\right)$ using the intensity ratio under nitrogen and oxygen was given in Table 2 also. It can be found that the sensitivity of the micelles with fluorine-containing polymers is higher than that of $\mathbf{P 2}$ without fluorine moieties, further exhibiting the suitableness and advantage of the fluorine-containing amphiphilic block copolymers as carriers for PtTFPP for sensing.
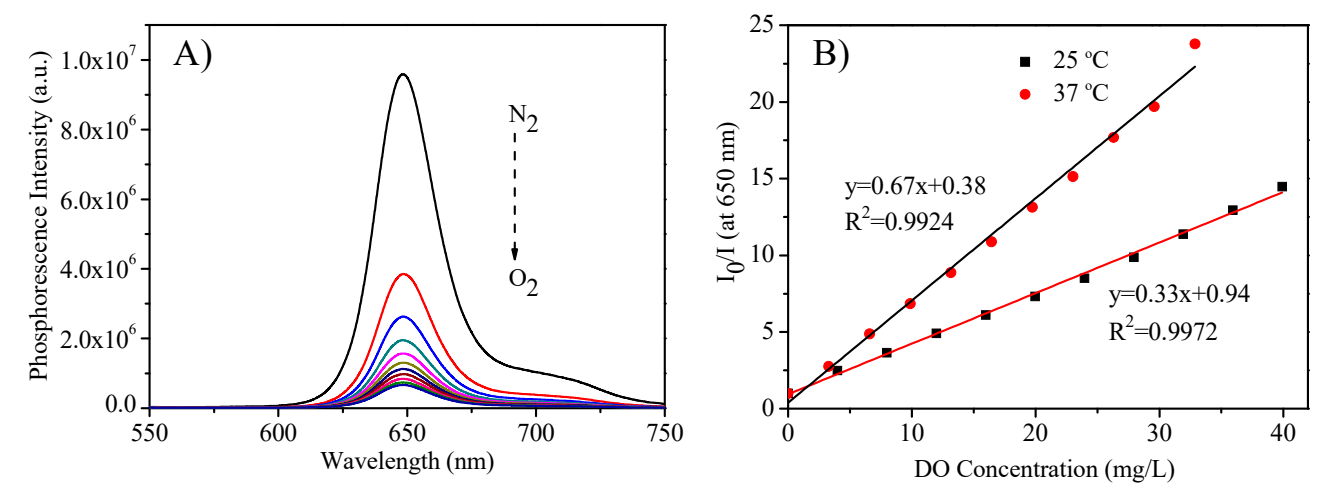

Figure 4. (A): Oxygen responses of $\mathbf{M} 3$ at $25^{\circ} \mathrm{C}$; (B): Stern-Volmer plot of $\mathbf{M} 3$ to oxygen at $25^{\circ} \mathrm{C}$ and $37^{\circ} \mathrm{C}$. $I_{0}$ is PtTFPP maximum phosphorescence intensity at $650 \mathrm{~nm}$ under hypoxia condition; $I$ is the intensity at $650 \mathrm{~nm}$ under various dissolved oxygen (DO) concentrations.

The lifetime of the PtTFPP in micelles was also evaluated briefly under air and hypoxia conditions, respectively. Figure S3E showed the representative changes of the $\mathbf{P} 3$ micelles, the lifetime of $\mathbf{M} 3$ was $18 \mu$ s under the air condition and $76 \mu$ s under the nitrogen condition (Table 2). Therefore, these PtTFPP-containing micelles formed from 4-arm fluoropolymers were suitable for long lifetime imaging which possesses high contrast, high sensitivity, no autofluorescence and no background interference [49].

Sensors' response time was evaluated by alternating the oxygenated and deoxygenated conditions through the bubbling of nitrogen and oxygen into the solutions. Figure 5 showed the representative response time and reversibility test by using micelles $\mathbf{M} 3$. The response time from the deoxygenated condition to oxygenated condition at 95\% equilibrium ( $\left.t_{95}\right)$ was $27 \mathrm{~s}$, while the reverse one was $198 \mathrm{~s}$ $\left(t_{95-r}\right)$. The $t_{95} \mathrm{~s}$ for these micelles (27-34 s, Table 2) were generally in accordance with those of 24-34 s reported by using other micelles previously [26,27]. We also measured M3`s response time with glucose oxidase (Figure S5). The result showed that when the activities of glucose oxidase (GOx) were 400, 100, 5, 2.5 and $1 \mathrm{U} / \mathrm{mL}$, the times of that $\mathbf{M} 3$ required to reach maximum intensity were $6 \mathrm{~s}, 20 \mathrm{~s}, 50 \mathrm{~s}, 90 \mathrm{~s}$, $350 \mathrm{~s}$, respectively. Results showed that when the enzyme concentration is high enough, the response of M3 to oxygen consumption is very fast. The integration of the gas-equilibration and glucose-oxidation methods demonstrated that our sensor is sensitive to real-time oxygen concentration changes. 


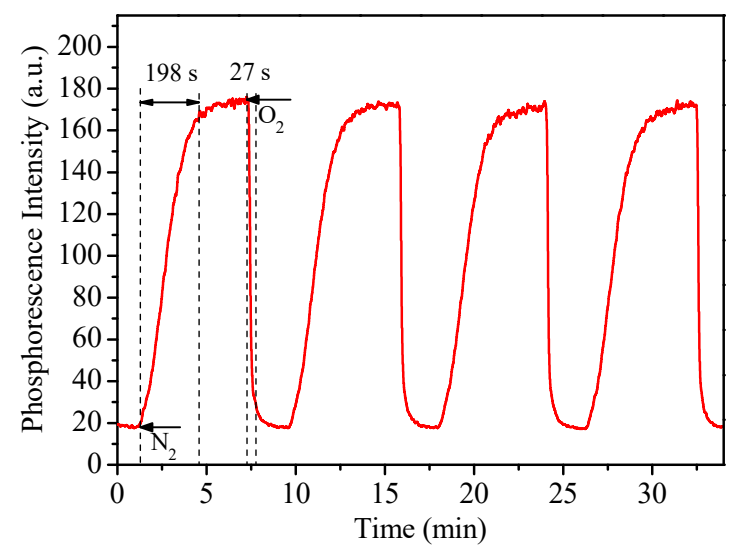

Figure 5. Dynamic phosphorescence intensity curve of M3 when the atmosphere switches between $100 \%$ of oxygen and $100 \%$ of nitrogen.

\subsection{The Use of the Sensors for Monitoring Cellular Respiration}

3.5.1. Monitoring the Oxygen Consumption during the Growth of E. coli and the Cytotoxicity Evaluation

M3 was added into the LB cell culture medium with different densities of E. coli JM109 cells to monitor the oxygen consumption during the cell growth. For accomplishing the experiment faster, a thin layer of mineral oil was added on the top of the LB medium to eliminate the exchange of oxygen in the medium with air. The contrast experiment without the use of mineral oil was also performed and experimental data were given in Figure S6. Figure 6A showed the time-dependent emission intensity changes with the use of mineral oil, respectively. Higher cells induced earlier phosphorescence intensity changes and reached emission maximum within a shorter time; while the phosphorescence intensity without $E$. coli was not increased. Figure $6 \mathrm{~B}$ showed the corresponding oxygen concentration changes. E. coli with a higher density consumed oxygen faster, showing the capacity of the micelles for cell respiration monitoring.

Micelles' potential cytotoxicity to E. coli was evaluated by monitoring cell density changes with and without sensors. Figure 7A gave the cell growth curve with a consistent PtTFPP concentration (10 $\mu \mathrm{g} / \mathrm{mL}$ ) at different $E$. coli densities. Figure 7B plotted the E. coli growth curve with a defined E. coli density but using various sensors concentrations. No E. coli growth inhibition was observed, showing the nontoxicity of the sensor to E. coli.
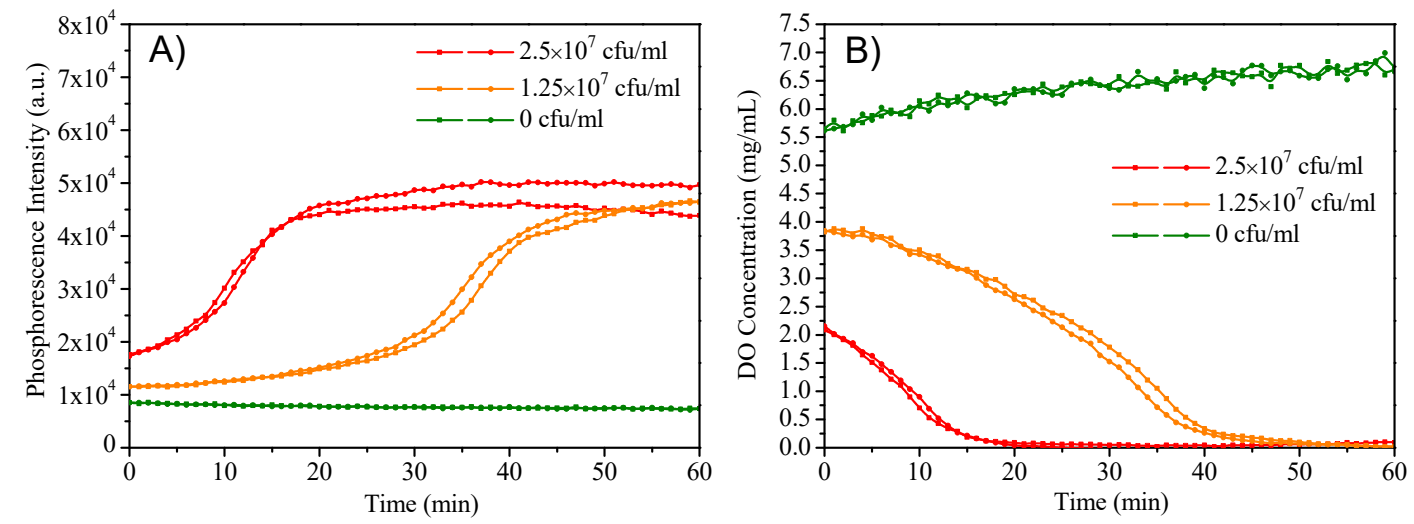

Figure 6. (A): Dynamic phosphorescence intensity curve of M3 measured by plate reader to determine the E. coli respiration. (B): Extracellular oxygen consumption by E. coli. 

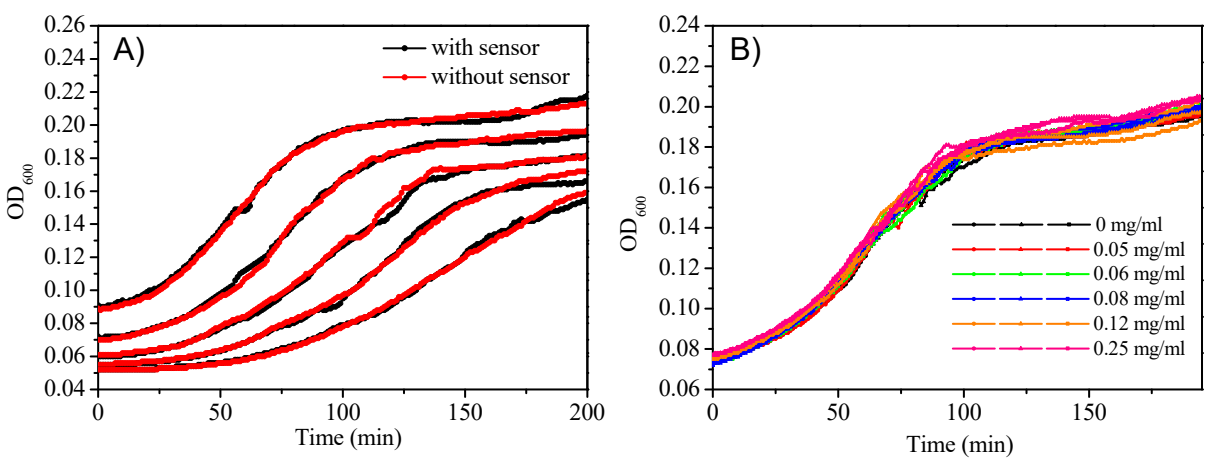

Figure 7. (A): Cell growth of $E$. coli with and without $\mathrm{M} 3$ monitored by $\mathrm{OD}_{600}$; (B): Cell growth of $E$. coli with a consistent of cell density however different concentrations of M3 monitored by $\mathrm{OD}_{600}$.

\subsubsection{Monitoring Cell Respiration of J774A.1 Cells}

We also extended the sensor's application to mammalian cells by using J774A.1 as a representative cell line. Figure 8 showed the time and cell concentration-dependent emission intensity changes. Similar to the phenomenon of E. coli, higher cell numbers induced faster oxygen consumption. Cell cytotoxicity was evaluated by using 3-(4,5-dimethyl-2-thiazolyl)-2,5-diphenyl-2-H-tetrazolium bromide (MTT) assay (Figure 9). No obvious cell cytotoxicity was observed.

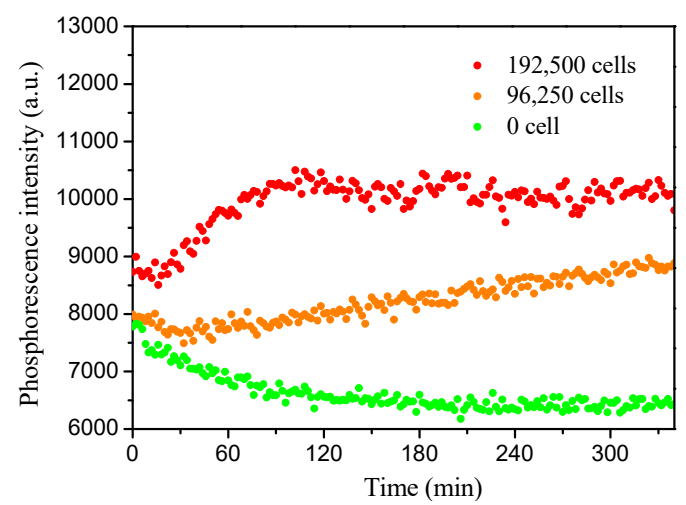

Figure 8. Cell respiration measurements of macrophages J774A.1 cells. Each well contained $10 \mu \mathrm{g} / \mathrm{mL}$ of PtTFPP in M3 and was sealed with mineral oil. The phosphorescence intensity (excitation: $405 \mathrm{~nm}$, emission: $650 \mathrm{~nm}$ ) was measured by a plate reader at $37^{\circ} \mathrm{C}$.

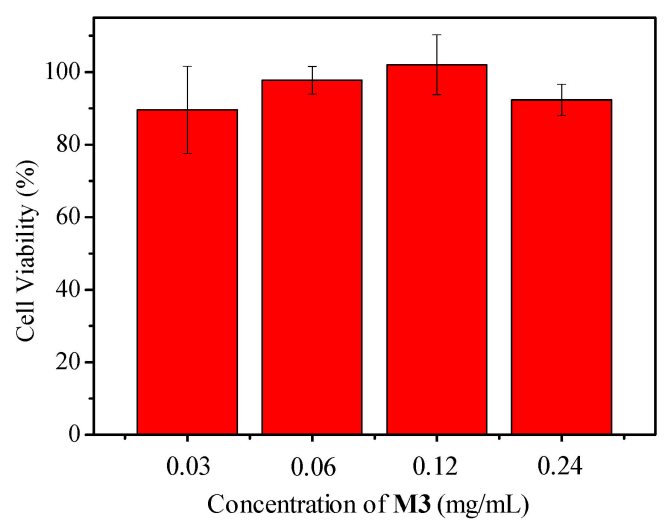

Figure 9. Viability of J774A.1 cells to different M3 concentrations $(0.24 \mathrm{mg} / \mathrm{mL}$ of $\mathrm{M} 3$ contained $0.04 \mathrm{mg} / \mathrm{mL}$ of PtTFPP) after $24 \mathrm{~h}$ cell internalization measured by MTT assay. Initial cell concentration was 10,000 cells per well in a 96 well plate. Each measurement was repeated five times. 


\subsection{In Vivo Hypoxia Imaging}

Besides the use of the sensors for in vitro studies, we explored whether the sensors are suitable for in vivo hypoxia imaging. The mouse was intratumorally injected $50 \mu \mathrm{L}$ (contained $0.3 \mathrm{mg} / \mathrm{mL}$ of PtTFPP and $1.9 \mathrm{mg} / \mathrm{mL}$ of P3) of M3 (Figure S7 showed M3 injection did not influence the change trend of mice's weight within 7 days, so M3 was nontoxic to tumor-bearing mice). After anesthesia, the phosphorescence image and intensity were gained by In Vivo Imaging System (Figure 10). Region of interest (ROI) 1 is the tumor region and ROI 2 is the normal region. It can be seen that the phosphorescence image at ROI 1 is much brighter. The phosphorescence intensity from ROI 1 is 1.6 times higher than that of ROI 2. This result demonstrated that the phosphorescence signal from oxygen sensors at the hypoxia site is stronger than the normal sites, indicating the sensors can be used for tumor diagnosis and imaging because the oxygen concentration at tumor sites are often under the hypoxia situation [50]. Moreover, the phosphorescence imaging lasted for at least 10 min without obvious decay of the phosphorescence signal after M3 injection (Figure S8), indicating that the PtTFPP possessed excellent in vivo stability and strong phosphorescence signal after being encapsulated by P3. Thus, the sensors reported here might be capable for in vivo tumor imaging. It is expected that the further use of the sensors can be extended to measure the intravascular oxygen contents, which will be more instructive to cancer prevention and cancer clinical analysis.

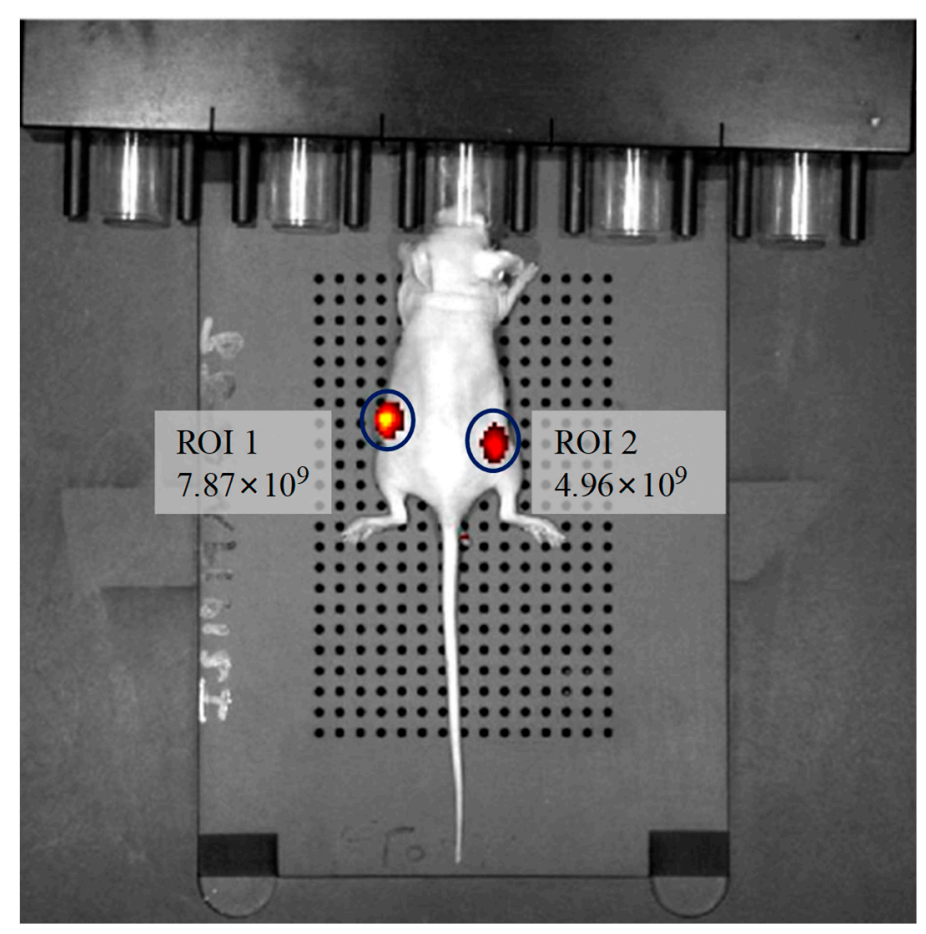

Figure 10. In vivo imaging of a tumor-bearing nude mouse after injection of $\mathbf{M} 3$, collocating with a bandpass filter (excitation: $430 \pm 15 \mathrm{~nm}$, emission: $640 \pm 10 \mathrm{~nm}$ ). ROI 1 was tumor and ROI 2 was normal skin.

\section{Conclusions}

Five amphiphilic multi-arm block polymers were synthesized successfully and used to encapsulate the hydrophobic oxygen probe PtTFPP in their micelles. This method enabled the use of PtTFPP in the biological environment. Further, high quantum efficiency as high as $22.3 \%$ and/or long lifetime as long as $76 \mu$ s of the PtTFPP molecules in micelles under nitrogen were achieved without chemical modification of the PtTFPP. Structure influences on photophysical properties were observed among the five polymers. The results showed that the fluorine-containing micelles exhibit greater oxygen sensitivity and longer phosphorescence lifetime than the micelles formed from the fluorine-free block 
copolymers due to the synergy of fluorine moieties. Representative micelles M3 formed from P3 and PtTFPP were used for the monitoring of E. coli JM109 and macrophage J774A.1. cells' respiration. Hypoxic tumor imaging of Balb/c nude mice was carried out successfully by using micelles M3. An obvious difference was found between the tumor and normal region because of the hypoxia condition in the tumor site. This study reported new oxygen sensors, elucidated structure influences on the photophysical properties of PtTFPP and oxygen sensing properties, and demonstrated the real-time monitoring cell respiration and in vivo hypoxia imaging at tumor sites. It is expected that this approach can be extended to other sensors and imaging probes for new multifunctional materials for further applications in clinical diagnoses and cancer therapy by taking the advantages of the materials' biocompatibility, nontoxicity, non-invasive measurements, and long phosphorescence lifetime.

Supplementary Materials: The following are available online at http:/ / www.mdpi.com/1424-8220/18/11/3752/ s1, Figures S1-S8: title.

Author Contributions: J.L. designed and performed most of the experiments, and wrote the draft; Y.Q. and T.P. helped with some cell respiration measurements; K.Z. and J.W. participated in some oxygen titration experiments; S.W. and F.S. participated in the discussions; Y.T. revised this manuscript and guided the design and discussion.

Funding: This research was funded by the National Natural Science Foundation of China (21574061, 21604036, 21774054), Special Funds for Shenzhen's Scientific and Technological Innovation (Grant No. GRCK2017042410542096), Student's Platform for Innovation and Entrepreneurship Training Program (Grant No. 2018S11), and the High-Level university construction fund for SUSTech (G01256018).

Conflicts of Interest: The authors declare no conflicts of interest.

\section{References}

1. Vaupel, P.; Hoeckel, M.; Mayer, A. Detection and characterization of tumor hypoxia using $\mathrm{PO}_{2}$ histography. Antioxid. Redox Signal. 2007, 9, 1221-1235. [CrossRef] [PubMed]

2. Iwai, T.; Obara, K.; Ito, C.; Furukawa, H.; Oka, J.-I. Hydroxyobtustyrene protects neuronal cells from chemical hypoxia-induced cell death. J. Nat. Med. 2018, 72, 915-921. [CrossRef] [PubMed]

3. Koehler, U.; Hildebrandt, O.; Kroenig, J.; Grimm, W.; Otto, J.; Hildebrandt, W.; Kinscherf, R. Chronic hypoxia and cardiovascular risk. Clinical significance of different forms of hypoxia. Herz 2018, 43, 291-297. [CrossRef] [PubMed]

4. Schramm, A.; Grunewald, S.; Lorenz, R.; Classen, J.; Naumann, M. Parkinsonism due to bilateral basal ganglia lesions following mastocytosis-induced hypoxia. J. Neurol. 2004, 251, 1270-1272. [CrossRef] [PubMed]

5. Salminen, A.; Kauppinen, M.; Kaamiranta, K. Hypoxia/ischemia activate processing of amyloid precursor protein: Impact of vascular dysfunction in the pathogenesis of Alzheimer's disease. J. Neurochem. 2017, 140, 536-549. [CrossRef] [PubMed]

6. Thienpont, B.; Steinbacher, J.; Zhao, H.; D'Anna, F.; Kuchnio, A.; Ploumakis, A.; Ghesquiere, B.; Van Dyck, L.; Boeckx, B.; Schoonjans, L.; et al. Tumour hypoxia causes DNA hyper-methylation by reducing TET activity. Nature 2016, 537, 63-68. [CrossRef] [PubMed]

7. Sun, X.; He, G.; Qing, H.; Zhou, W.; Dobie, F.; Cai, F.; Staufenbiel, M.; Huang, L.E.; Song, W. Hypoxia facilitates Alzheimer's disease pathogenesis by up-regulating BACE1 gene expression. Proc. Natl. Acad. Sci. USA 2006, 103, 18727-18732. [CrossRef] [PubMed]

8. Semenza, G.L. Oxygen sensing, hypoxia-inducible factors, and disease pathophysiology. Annu. Rev. Pathol. Mech. Dis. 2014, 9, 47-71. [CrossRef] [PubMed]

9. Giaccia, A.J.; Simon, M.C.; Johnson, R. The biology of hypoxia: The role of oxygen sensing in development, normal function, and disease. Genes Dev. 2004, 18, 2183-2194. [CrossRef] [PubMed]

10. Kinoshita, K. Electrochemical Oxygen Technology; Wiley: New York, NY, USA, 1992.

11. Winkler, L.W. Die bestimmung des im wasser gelösten sauerstoffes. Eur. J. Inorg. Chem. 1888, 21, $2843-2854$. [CrossRef]

12. Han, B.H.; Manners, I.; Winnik, M.A. Phosphorescence quenching of dyes adsorbed to silica thin-layer chromatography plates. Anal. Chem. 2005, 77, 8075-8085. [CrossRef] [PubMed]

13. Moos, R. Solid State Gas Sensors-Industrial Application; Fleischer, M., Lehmann, M., Eds.; Springer: Berlin/Heidelberg, Germany, 2011; pp. 173-188. 
14. Wang, X.; Wolfbeis, O.S. Optical methods for sensing and imaging oxygen: Materials, spectroscopies and applications. Chem. Soc. Rev. 2014, 43, 3666-3761. [CrossRef] [PubMed]

15. Yoshihara, T.; Hirakawa, Y.; Hosaka, M.; Nangaku, M.; Tobita, S. Oxygen imaging of living cells and tissues using luminescent molecular probes. J. Photochem. Photobiol. C 2017, 30, 71-95. [CrossRef]

16. Pereira, N.A.M.; Laranjo, M.; Casalta-Lopes, J.; Serra, A.C.; Pineiro, M.; Pina, J.; Sergio Seixas de Melo, J.; Senge, M.O.; Botelho, F.M.; Martelo, L.; et al. Platinum (II) ring-fused chlorins as near-infrared emitting oxygen sensors and photodynamic agents. ACS Med. Chem. Lett. 2017, 8, 310-315. [CrossRef] [PubMed]

17. Zeng, Y.; Liu, Y.; Shang, J.; Ma, J.; Wang, R.; Deng, L.; Guo, Y.; Zhong, F.; Bai, M.; Zhang, S.; et al. Phosphorescence monitoring of hypoxic microenvironment in solid-tumors to evaluate chemotherapeutic effects using the hypoxia-sensitive Iridium (III) coordination compound. PLoS ONE 2015, 10, e0121293. [CrossRef] [PubMed]

18. Eastwood, D.; Gouterma, M. Porphyrins XVIII luminescence of (Co), (Ni), Pd, Pt complexes. J. Mol. Spectrosc. 1970, 35, 359-375. [CrossRef]

19. Sun, K.; Tang, Y.; Li, Q.; Yin, S.; Qin, W.; Yu, J.; Chiu, D.T.; Liu, Y.; Yuan, Z.; Zhang, X.; et al. In vivo dynamic monitoring of small molecules with implantable polymer-dot transducer. ACS Nano 2016, 10, 6769-6781. [CrossRef] [PubMed]

20. Sakadzic, S.; Roussakis, E.; Yaseen, M.A.; Mandeville, E.T.; Srinivasan, V.J.; Arai, K.; Ruvinskaya, S.; Devor, A.; Lo, E.H.; Vinogradov, S.A.; et al. Two-photon high-resolution measurement of partial pressure of oxygen in cerebral vasculature and tissue. Nat. Methods 2010, 7, 755-759. [CrossRef] [PubMed]

21. Zhao, Q.; Zhou, X.; Cao, T.; Zhang, K.Y.; Yang, L.; Liu, S.; Liang, H.; Yang, H.; Li, F.; Huang, W. Fluorescent/phosphorescent dual-emissive conjugated polymer dots for hypoxia bioimaging. Chem. Sci. 2015, 6, 1825-1831. [CrossRef] [PubMed]

22. Shi, H.; Ma, X.; Zhao, Q.; Liu, B.; Qu, Q.; An, Z.; Zhao, Y.; Huang, W. Ultrasmall phosphorescent polymer dots for ratiometric oxygen sensing and photodynamic cancer therapy. Adv. Funct. Mater. 2014, 24, 4823-4830. [CrossRef]

23. Dmitriev, R.I.; Borisov, S.M.; Duessmann, H.; Sun, S.; Mueller, B.J.; Prehn, J.; Baklaushev, V.P.; Klimant, I.; Papkovsky, D.B. Versatile conjugated polymer nanoparticles for high-resolution $\mathrm{O}_{2}$ imaging in cells and 3D tissue models. ACS Nano 2015, 9, 5275-5288. [CrossRef] [PubMed]

24. Lemon, C.M.; Karnas, E.; Han, X.; Bruns, O.T.; Kempa, T.J.; Fukumura, D.; Bawendi, M.G.; Jain, R.K.; Duda, D.G.; Nocera, D.G. Micelle-encapsulated quantum dot-porphyrin assemblies as in vivo two-photon oxygen sensors. J. Am. Chem. Soc. 2015, 137, 9832-9842. [CrossRef] [PubMed]

25. Su, F.; Alam, R.; Mei, Q.; Tian, Y.; Youngbull, C.; Johnson, R.H.; Meldrum, D.R. Nanostructured oxygen sensor-using micelles to incorporate a hydrophobic platinum porphyrin. PLOS ONE 2012, 7, e33390. [CrossRef] [PubMed]

26. Zou, X.; Pan, T.; Jiang, J.; Li, G.; Song, C.; Sun, R.; Yang, Z.; Sun, D.; Hou, C.; Chen, M.; et al. Poly(epsilon-caprolactone)-containing graft copolymers for ratiometric extracellular oxygen sensing. Sens. Actuator B Chem. 2017, 248, 108-118. [CrossRef]

27. Zhao, Q.; Pan, T.; Xiang, G.; Mei, Z.; Jiang, J.; Li, G.; Zou, X.; Chen, M.; Sun, D.; Jiang, S.; et al. Highly efficient ratiometric extracellular oxygen sensors through physical incorporation of a conjugated polymer and PtTFPP in graft copolymers. Sens. Actuator B Chem. 2018, 273, 242-252. [CrossRef]

28. Matyjaszewski, K.; Miller, P.J.; Pyun, J.; Kickelbick, G.; Diamanti, S. Synthesis and characterization of star polymers with varying arm number, length, and composition from organic and hybrid inorganic/organic multifunctional initiators. Macromolecules 1999, 32, 6526-6535. [CrossRef]

29. Ren, J.M.; McKenzie, T.G.; Fu, Q.; Wong, E.H.H.; Xu, J.; An, Z.; Shanmugam, S.; Davis, T.P.; Boyer, C.; Qiao, G.G. Star Polymers. Chem. Rev. 2016, 116, 6743-6836. [CrossRef] [PubMed]

30. Liu, G.; Fan, W.; Li, L.; Chu, P.K.; Yeung, K.W.K.; Wu, S.; Xu, Z. Novel anionic fluorine-containing amphiphilic self-assembly polymer micelles for potential application in protein drug carrier. J. Fluor. Chem. 2012, 141, 21-28. [CrossRef]

31. Westbrook, A.W.; Ren, X.; Moo-Young, M.; Chou, C.P. Application of hydrocarbon and perfluorocarbon oxygen vectors to enhance heterologous production of hyaluronic acid in engineered bacillus subtilis. Biotechnol. Bioeng. 2018, 115, 1239-1252. [CrossRef] [PubMed]

32. Lee, W.W.S.; Wong, K.Y.; Li, X.M.; Leung, Y.B.; Chan, C.S.; Chan, K.S. Halogenated platinum porphyrins as sensing materials for luminescence-based oxygen sensors. J. Mater. Chem. 1993, 3, 1031-1035. [CrossRef] 
33. Rosen, M.J.; Mathias, J.H.; Davenport, L. Aberrant aggregation behavior in cationic gemini surfactants investigated by surface tension, interfacial tension, and fluorescence methods. Langmuir 1999, 15, 7340-7346. [CrossRef]

34. Chen, C.-Y.; Kim, T.H.; Wu, W.-C.; Huang, C.-M.; Wei, H.; Mount, C.W.; Tian, Y.; Jang, S.-H.; Pun, S.H.; Jen, A.K.Y. pH-dependent, thermosensitive polymeric nanocarriers for drug delivery to solid tumors. Biomaterials 2013, 34, 4501-4509. [CrossRef] [PubMed]

35. Lai, S.W.; Hou, Y.J.; Che, C.M.; Pang, H.L.; Wong, K.Y.; Chang, C.K.; Zhu, N.Y. Electronic spectroscopy, photophysical properties, and emission quenching studies of an oxidatively robust perfluorinated platinum porphyrin. Inorg. Chem. 2004, 43, 3724-3732. [CrossRef] [PubMed]

36. Joshi, H.S.; Jamshidi, R.; Tor, Y. Conjugated 1,10-phenanthrolines as tunable fluorophores. Angew. Chem. Int. Ed. 1999, 38, 2722-2725. [CrossRef]

37. Khanna, K.; Varshney, S.; Kakkar, A. Miktoarm star polymers: Advances in synthesis, self-assembly, and applications. Polym. Chem. 2010, 1, 1171-1185. [CrossRef]

38. Ge, Z.; Liu, S. Supramolecular self-assembly of nonlinear amphiphilic and double hydrophilic block copolymers in aqueous solutions. Macromol. Rapid Commun. 2009, 30, 1523-1532. [CrossRef] [PubMed]

39. Matyjaszewski, K. Atom transfer radical polymerization (ATRP): Current status and future perspectives. Macromolecules 2012, 45, 4015-4039. [CrossRef]

40. Palmiero, U.C.; Sponchioni, M.; Manfredini, N.; Maraldi, M.; Moscatelli, D. Strategies to combine ROP with ATRP or RAFT polymerization for the synthesis of biodegradable polymeric nanoparticles for biomedical applications. Polym. Chem. 2018, 9, 4084-4099. [CrossRef]

41. Boyer, C.; Corrigan, N.A.; Jung, K.; Diep, N.; Thuy-Khanh, N.; Adnan, N.N.M.; Oliver, S.; Shanmugam, S.; Yeow, J. Copper-mediated living radical polymerization (atom transfer radical polymerization and copper (0) mediated polymerization): From fundamentals to bioapplications. Chem. Rev. 2016, 116, 1803-1949. [CrossRef] [PubMed]

42. Jones, M.C.; Leroux, J.C. Polymeric micelles-A new generation of colloidal drug carriers. Eur. J. Pharm. Biopharm. 1999, 48, 101-111. [CrossRef]

43. Xu, R.; Wang, Y.; Duan, X.; Lu, K.; Micheroni, D.; Hu, A.; Lin, W. Nanoscale Metal-organic frameworks for ratiometric oxygen sensing in live cells. J. Am. Chem. Soc. 2016, 138, 2158-2161. [CrossRef] [PubMed]

44. Fercher, A.; Borisov, S.M.; Zhdanov, A.V.; Klimant, I.; Papkovsky, D.B. Intracellular $\mathrm{O}_{2}$ sensing probe based on cell-penetrating phosphorescent nanoparticles. ACS Nano 2011, 5, 5499-5508. [CrossRef] [PubMed]

45. Lehner, P.; Larndorfer, C.; Garcia-Robledo, E.; Larsen, M.; Borisov, S.M.; Revsbech, N.-P.; Glud, R.N.; Canfield, D.E.; Klimant, I. LUMOS-A Sensitive and Reliable Optode System for Measuring Dissolved Oxygen in the Nanomolar Range. PLoS ONE 2015, 10, e0128125. [CrossRef] [PubMed]

46. O’Riordan, T.C.; Fitzgerald, K.; Ponomarev, G.V.; Mackrill, J.; Hynes, J.; Taylor, C.; Papkovsky, D.B. Sensing intracellular oxygen using near-infrared phosphorescent probes and live-cell fluorescence imaging. Am. J. Physiol.-Reg. Integr. Comp. Physiol. 2007, 292, R1613-R1620. [CrossRef] [PubMed]

47. Esipova, T.V.; Karagodov, A.; Miller, J.; Wilson, D.F.; Busch, T.M.; Vinogradov, S.A. Two new "protected" oxyphors for biological oximetry: Properties and application in tumor imaging. Anal. Chem. 2011, 83, 8756-8765. [CrossRef] [PubMed]

48. Tian, Y.; Shumway, B.R.; Meldrum, D.R. A new cross-linkable oxygen sensor covalently bonded into poly(2-hydroxyethyl methacrylate)-co-polyacrylamide thin film for dissolved oxygen sensing. Chem. Mater. 2010, 22, 2069-2078. [CrossRef] [PubMed]

49. Baggaley, E.; Botchway, S.W.; Haycock, J.W.; Morris, H.; Sazanovich, I.V.; Williams, J.A.G.; Weinstein, J.A. Long-lived metal complexes open up microsecond lifetime imaging microscopy under multiphoton excitation: From FLIM to PLIM and beyond. Chem. Sci. 2014, 5, 879-886. [CrossRef]

50. Vaupel, P.; Harrison, L. Tumor hypoxia: Causative factors, compensatory mechanisms, and cellular response. Oncologist 2004, 9, 4-9. [CrossRef] [PubMed]

(C) 2018 by the authors. Licensee MDPI, Basel, Switzerland. This article is an open access article distributed under the terms and conditions of the Creative Commons Attribution (CC BY) license (http:/ / creativecommons.org/licenses/by/4.0/). 